\title{
Workability and Strength Characteristics of Concrete by the Partial Reuse of Waste Plastic in Place of Natural Sand
}

\author{
R.Venkatakrishniah, P. Dayakar, K. Venkat Raman
}

\begin{abstract}
In present the development cost as absence of sand is improving step by step so as to check this issue, sand is in part supplant in type of plastic wastes material. Plastic waste is reused in type of the generation of new material which might be utilized as discretionary part in concrete and is probably the most ideal ways for disposing of plastic waste. Additionally these procedures demonstrated to be profoundly practical than standard technique. The target of this thesis is to use plastic waste as a discretionary substitution $(0 \%, 10 \%, 20 \%, 40 \%$ and $60 \%)$ of natural sand and test it for various strength characteristics and supportability.
\end{abstract}

Keywords - Recycle, Plastic waste, Concrete, Workability, Slump

\section{INTRODUCTION}

The mixture of concrete is a prevalently utilized material on the planet. In excess of 10 billion tons of cement are devoured yearly[1]-[4]. Rely upon generally use it is settled at second position after water. Traditional concrete, a unique material is a mix of bond, sand, total and water. Total content is the factor, which are immediate and extensive impacts on the property of cement. In contrast to water and concrete, which don't amalgam a specific trademark with the exception of the amount wherein it is utilized, the total part is interminably factor fit as a fiddle and reviewing. Top quality total, both coarse and fine for concrete, is of very extraordinary significance. Totals expend 60 to $80 \%$ of the complete base volume of cement and influence on the crisp and solidified particles of cement. Out of the all out arrangement of cement, the fine total devours around 18 to $30 \%$ of the volume[5]-[7].

\section{A. Difficulties of Using Natural River Sand}

Regular Sand is inadequate in numerous perspectives when utilized straightforwardly for solid creation. Extraction of the sand from stream bed in overabundance amount is unsafe to the earth. It is a typical sight that well establishments of the extensions are uncovered significantly, because of over the top extraction of sand around the sub structure jeopardizing the sub structure of the scaffolds. Over the top mining of the

Revised Manuscript Received on October 22, 2019.

R.Venkatakrishniah, Department of Civil Engineering, Bharath Institute of Higher Education and Research, Chennai, India. Email: venkatapec@gmail.com

P. Dayakar, Department of Civil Engineering, Bharath Institute of Higher Education and Research, Chennai , India. Email: dayakarpitti@yahoo.co.in

K. Venkat Raman, Department of Civil Engineering, Bharath Institute of Higher Education and Research, Chennai, India. Email: venkatraman.civil@bharathuniv.ac.in sand from waterway beds lessens the water head. This is because of the less permeation of water in the ground. The nonappearance of sand in waterway bed brings about more water being dissipated[8].

\section{B. Recycle Plastic}

Plastic is one of the materials demonstrating huge potential in our day by day lives as it have low thickness, high quality, easy to use plans, creation abilities and minimal effort attributes the components which unprecedented development. In spite of the fact that, plastics have been utilized in enormous and valuable applications, it gives to a consistently expanding sum in the strong waste stream. Polyethylene frames the biggest division, which is trailed by Polyethylene Concrete is the most broadly utilized development material on the planet because of its high compressive quality, long assistance life, and ease[9]-[12]. In field of solid innovation, India just as other country presently is looking for an option for traditional total that might be perceived as utilize plastic waste, for it may be acknowledged as PET stage limits. According to the evaluations, India produces 500,000 tons of pet squander each year. Mostly plastic waste delivered from the dispose of water bottles. At present, the absolute reusing limit in India is around 145,000 TPA its utilization in solid blend will demonstrate a superior alternative for land fill that, being non-degradable, stay for long years and cause issue before us. These days, lamentably, the reusing pace of PET jugs is considerably less than the offers of virgin PET creation for basic uses, a potential application is to use squander PET pieces as substitution of fine totals in concrete. Plastics Packaging sums $42 \%$ of complete utilization and consistently little of this is reused[13]-[14].

\section{LITERATURE REVIEW}

Researchers are going in and around the world for the utilization of various wastes for different purposes. Here some of the previous studies to replace fine aggregate in concrete with various Recycle plastic wastes are discussed.

Shyam and Drishya (2018) in their work a study on the partial use of $\mathrm{M}$ sand with high density polyethylene powder is carried out. A differentiation between normal concrete and concrete with HDPE powder was used to study the capacity and life parameters. In this work 5, 10, 15 and 20 percentage

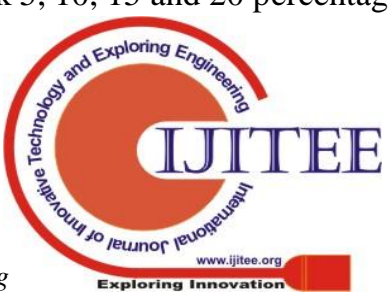


replacement of M sand with HDPE powder is experimented. Based on the results and observations of the experimental work conducted, the following conclusions are drawn: that plastic waste can be disposed by using them as a building material in concrete. Workability decreases with increase in HDPE powder. Compressive strength, flexural strength and split tensile strength of concrete decreases with increase in HDPE powder. The optimum percentage of replacement by HDPE powder in terms of workability and strength is obtained as $5 \%$.Compressive strength increases up to $16.6 \%$ for 5\% replacement of HDPE powder. Split tensile strength increases up to $22.815 \%$ for $5 \%$ replacement of HDPE powder. Flexural strength increases up to $46.34 \%$ for $5 \%$ replacement of HDPE powder.

Charudatta P. Thosar, Dr.M.Husain (2017) in their test examination supplanted the common waterway sand by utilizing the plastic waste which is reusing from PET or PP squander. Fractional substitution of sand by plastic squander material is finished with M20 evaluation of cement. Plastic squander where used to supplant $20 \%, 40 \%$ and $60 \%$ of regular waterway sand in the solid blends and tried following 28 days for compressive quality, elasticity, flexural quality and adjusted thickness of cement. The trial uncovered that the incomplete substitution of plastic waste material should be possible to a furthest reaches of $20 \%$ to $40 \%$ for the palatable properties of solid which is adequate utmost for the constructional reason in the common business.

As indicated by researchers the drop in compressive qualities because of the expansion of plastic waste aggregates can be ascribed for the most part to the less adhesion in between the framework and plastic aggregates.

As indicated by the creators, a lessening of $9.5 \%$ and $17.9 \%$ for blends with, individually, 20\% and half of PET-totals is watched. For blends with half of PC totals, a diminishing of $32.8 \%$ is estimated. The creators found that the determined flexural sturdiness factors increment fundamentally with expanding volume division of plastic totals. In this manner, the expansion of plastic totals in cementatious materials can give a decent vitality engrossing material.

\section{RESULTS AND DISCUSSIONS}

\section{A. Workability of Concrete by Compaction Factor Test}

Workability of concrete is an important property to determine before placing of concrete. Concrete with high compaction factor is said to be more workable[15]-[17].

Table 1 - Compaction Factor of Concrete W.R.T. Plastic waste Percentage

\begin{tabular}{|c|c|}
\hline $\begin{array}{c}\text { Plastic waste } \\
\text { Percentage }\end{array}$ & $\begin{array}{c}\text { Compaction } \\
\text { Factor }\end{array}$ \\
\hline $0 \%$ & 0.94 \\
\hline $10 \%$ & 0.88 \\
\hline $20 \%$ & 0.86 \\
\hline $40 \%$ & 0.85 \\
\hline $60 \%$ & 0.84 \\
\hline
\end{tabular}

Table 1 shows values of compaction factor for the different values of plastic content in concrete. Concrete without plastic has high compaction factor whereas concrete with maximum plastic content showed lowest compaction factor.

The comparison of Compaction factor for various plastic content percentages: It is observed that as the polypropylene plastic content in concrete increases compaction factor of concrete decreases accordingly hence the workability decreases. So concrete with $0 \%$ plastic has high workability and concrete with $2.0 \%$ has lowest workability[18]-[20].

\section{A. Slump Test}

Table 2 - Slump with Plastic waste

\begin{tabular}{|c|c|c|}
\hline \multirow{2}{*}{ S. No. } & \multirow{2}{*}{$\begin{array}{c}\text { Plastic } \\
\text { waste } \%\end{array}$} & Slump (mm) \\
\cline { 3 - 3 } & & M25 \\
\hline 1 & 0.0 & 75 \\
\hline 2 & 10 & 68 \\
\hline 3 & 20 & 64 \\
\hline 4 & 40 & 61 \\
\hline 5 & 60 & 59 \\
\hline
\end{tabular}

\section{B. Compressive Strength of Concrete}

Characteristic compressive strength is the utmost property of normal cement concrete. Concrete specimens having dimensions $150 \mathrm{~mm} \times 150 \mathrm{~mm} \times 150 \mathrm{~mm}$ were casted and tested for characteristic strength on UTM testing machine[21]-[23].

Table 3 - Compressive strength of M25 grade

\begin{tabular}{|c|c|c|}
\hline \multirow{2}{*}{ Plastic waste $\%$} & \multicolumn{2}{|c|}{ Compressive Strength $\left(\mathrm{N} / \mathrm{mm}^{2}\right)$} \\
\hline & $\begin{array}{l}\text { After 14Days } \\
\text { of curing }\end{array}$ & $\begin{array}{c}\text { After } 28 \text { Days } \\
\text { of curing }\end{array}$ \\
\hline 0.0 & 21.5 & 26.83 \\
\hline 10 & 23.8 & 29.94 \\
\hline 20 & 26.8 & 33.65 \\
\hline 40 & 27.86 & 34.83 \\
\hline 60 & 22.4 & 27.8 \\
\hline
\end{tabular}




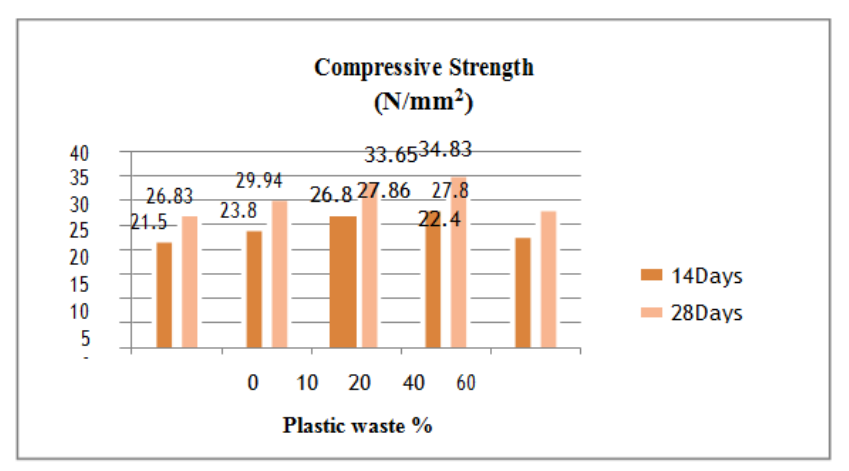

Figure 1 - Comparative Compressive Strength of M25 Grade

\section{Split Strength of Concrete in Tension}

Normally it is having very lower properties in tension, so the testing of cylinder specimen for tensile strength is required[24]-[28]. Cylinders of dimension 150mm (dia.) and $300 \mathrm{~mm}$ (length) were casted and tested for split strength on universal testing machine (UTM).

\begin{tabular}{|c|c|c|}
\hline \multirow{2}{*}{ Plastic waste \% } & \multicolumn{2}{|c|}{$\begin{array}{c}\text { Split Strength (Tension) } \\
\left(\mathrm{N} / \mathrm{mm}^{2}\right)\end{array}$} \\
\cline { 2 - 3 } & $\begin{array}{c}\text { After 14 Days } \\
\text { of curing }\end{array}$ & $\begin{array}{c}\text { After 28 Days of } \\
\text { curing }\end{array}$ \\
\hline 0.0 & 1.78 & 2.25 \\
\hline 10 & 1.95 & 2.42 \\
\hline 20 & 2.19 & 2.74 \\
\hline 40 & 2.7 & 3.27 \\
\hline 60 & 1.9 & 2.28 \\
\hline
\end{tabular}

Table 4 - Splitting Tensile Strength of M25 grade

\section{Flexural Strength of concrete}

Flexural quality is one proportion of the elasticity of cement[29]-[31]. It is a proportion of an unreinforced solid shaft or chunk to oppose disappointment in twisting. For flexural quality test light emissions $100 \mathrm{~mm} \times 100 \mathrm{~mm} \times 500$ $\mathrm{mm}$ were casted and tested on the bending testing machine.

\begin{tabular}{|c|c|c|}
\hline \multirow{2}{*}{$\begin{array}{c}\text { Plastic waste } \\
\%\end{array}$} & \multicolumn{2}{|c|}{ Flexural Strength $\left(\mathrm{N} / \mathrm{mm}^{2}\right)$} \\
\cline { 2 - 3 } & 28 Days & $\begin{array}{c}\text { Percentage } \\
\text { Increased }\end{array}$ \\
\hline 0.0 & 2.7 & - \\
\hline 10 & 2.8 & 11.53 \\
\hline 20 & 3.4 & 26.92 \\
\hline 40 & 3.5 & 30.77 \\
\hline 60 & 2.8 & 3.84 \\
\hline
\end{tabular}

Table 4 - Flexural Strength of M 25 Grade

\section{CONCLUSION}

In this experiment, mix design of M-25 grade concrete; reference IS 10262: 2009, having water-cement ratio 0.45 is considered. Percentage of plastic aggregates $(0 \%, 10 \%, 20 \%$, $40 \%$ and $60 \%$ ) is added in concrete. Specimens of plastic aggregate concrete were casted with great precision and were cured for 14 days and 28 days. During concreting/casting of cubes, workability tests were conducted on fresh concrete for verification of workability with above percentage (\%) addition of plastic waste i.e. ( $0 \%$ to $60 \%$ ). After completion of maturity period of curing all the strength tests were conducted on all the specimens with respective date of casting[32]-[34]. After this experiments, investigated that compression strength is increasing as the increase of plastic aggregate, after $40 \%$ of plastic aggregate the compressive strength is decreased. From this, it is clear that, the optimum dosage of plastic aggregate is $40 \%$ with respect to compressive strength for both curing periods (14 and 28 days).

The optimum percentage increment in split tensile strength was $51.68 \%$ for 14 days curing and $45.33 \%$ for 28 days at $40 \%$ plastic aggregate.

It was also noted that flexural strength of concrete increase gradually with addition of plastic aggregate and minimum flexural strength was obtained at $0 \%(2.7 \mathrm{~N} / \mathrm{mm} 2) .3 .5$ $\mathrm{N} / \mathrm{mm} 2$ optimum flexural strength was obtained with addition of $40 \%$ plastic aggregate after 28 days of curing.

Recommendations for Future Studies

For hardened concrete chemical attack is the main reason for the corrosion in concrete so plastic aggregate concrete is observed by experimental studies. After increasing its tensile strength, it can be used for dynamic structures also.

After increasing tensile and flexural strength of concrete it be can replace mechanically compacted concrete.

There is a huge scope in cost comparison of plastic aggregate concrete with different additives as fly ash, furnace slag etc.

After increasing the strength of concrete it can also be used in heavy structure as bridges, dames, foundation work etc.

Plastic aggregate concrete can also use in rigid pavement for impact load resistance on express way and highways which can use for landing of military tanks and aircraft landing.

\section{REFERENCES}

1. Iyappan L., Dayakar P., Identification of landslide prone zone for coonoortalukusing spatial technology, International Journal of Applied Engineering Research,V-9,I-22,PP-5724-5732,Y-2014.

2. Kumar J., Sathish Kumar K., Dayakar P.,Effect of microsilica on high strength concrete, International Journal of Applied Engineering Research,V-9,I-22,PP-5427-5432,Y-2014.

3. Dayakar P., Vijay Ruthrapathi G., Prakesh J., Management of bio-medical waste, International Journal of Applied Engineering Research,V-9,I-22,PP-5518-5526,Y-2014.

4. Swaminathan N., Dayakar P., Resource optimization in construction project, International Journal of Applied Engineering

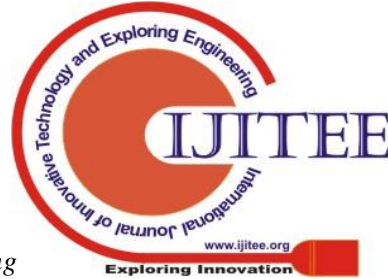


Research,V-9,I-22,PP-5546-5551,Y-2014.

5. Venkat Raman K., Dayakar P., Raju K.V.B.,An experimental study on effect of cone diameters in penetration test on sandy soil, International Journal of Civil Engineering and Technology,V-8,I-8,PP-1581-1588,Y-2017.

6. Saritha B., Chockalingam M.P.,Photodradation of malachite green DYE using TIO2/activated carbon composite, International Journal of Civil Engineering and Technology,V-8,I-8,PP-156-163,Y-2017

7. Shendge R.B., Chockalingam M.P., Saritha B., Ambica A.,Swat modelling for sediment yield: A case study of Ujjani reservoir in Maharashtra, India,International Journal of Civil Engineering and Technology,V-9,I-1,PP-245-252,Y-2018

8. Chockalingam M.P., Balamurgan V.,Modernisation of an existing urban road-sector in Chennai, a case study report,International Journal of Civil Engineering and Technology,V-8,I-8,PP-1457-1467,Y-2017

9. Saritha B., Chockalingam M.P.,Adsorption study on removal of basic dye by modified coconut shell adsorbent, International Journal of Civil Engineering and Technology,V-8,I-8,PP-1370-1374,Y-2017

10. Saritha B., Chockalingam M.P.,Adsorptive removal of heavy metal chromium from aqueous medium using modified natural adsorbent,International Journal of Civil Engineering and Technology,V-8,I-8,PP-1382-1387,Y-2017

11. Chockalingam M.P., Palanivelraja S.,Retrospective analysis of a theoretical model used for forecasting future air quality near the north Chennai thermal power plant,International Journal of Civil Engineering and Technology,V-8,I-8,PP-1457-1467,Y-2017

12. Saritha B., Chockalingam M.P.,Photodegradation of methylene blue dye in aqueous medium by $\mathrm{Fe}-\mathrm{AC} / \mathrm{TiO} 2$ Composite,Nature Environment and Pollution Technology,V-17,I-4,PP-1259-1265,Y-2018

13. Shendge R.B., Chockalingam M.P., Kaviya B., Ambica A.,Estimates of potential evapotranspiration rates by three methods in upper Bhima Basin, In Maharashtra, India,International Journal of Civil Engineering and Technology,V-9,I-2,PP-475-480,Y-2018

14. Shendge R.B., Chockalingam M.P.,The soil and water assessment tool for Ujjani Reservoir,International Journal of Mechanical Engineering and Technology,V-9,I-2,PP-354-359,Y-2018

15. Shendge R.B., Chockalingam M.P.,A review on soil and water assessment tool,International Journal of Mechanical Engineering and Technology,V-9,I-2,PP-347-353,Y-2018

16. Sachithanandam P., Meikandaan T.P., Srividya T.,Steel framed multi storey residential building analysis and design,International Journal of Applied Engineering Research,V-9,I-22,PP-5527-5529,Y-2014

17. Meikandaan T.P., Ramachandra Murthy A.,Study of damaged RC beams repaired by bonding of CFRP laminates, International Journal of Civil Engineering and Technology,V-8,I-2,PP-470-486,Y-2017

18. Meikandaan T.P., Ramachandra Murthy A.,Retrofittng of reinforced concrete beams using GFRP overlays,International Journal of Civil Engineering and Technology,V-8,I-2,PP-423-439,Y-2017

19. Meikandaan T.P., Ramachandra Murthy A.,Flexural behaviour of RC beam wrapped with GFRP sheets,International Journal of Civil Engineering and Technology,V-8,I-2,PP-452-469,Y-2017

20. Meikandaan T.P., Murthy A.R.,Experimental study on strengthening of rc beams using glass Fiber,International Journal of Civil Engineering and Technology,V-9,I-11,PP-959-965,Y-2018

21. Meikandaan T.P., Hemapriya M.,Use of glass FRP sheets as external flexural reinforcement in RCC Beam,International Journal of Civil Engineering and Technology,V-8,I-8,PP-1485-1501,Y-2017

22. Saraswathy R., Saritha B.,Planning of integrated satellite township at Thirumazhisai,International Journal of Applied Engineering Research,V-9,I-22,PP-5558-5560,Y-2014

23. Saritha B., Ilayaraja K., Eqyaabal Z.,Geo textiles and geo synthetics for soil reinforcement,International Journal of Applied Engineering Research,V-9,I-22,PP-5533-5536,Y-2014

24. Ambica A., Saritha B., Changring G., Singh N B., Rajen M., Salman Md.,Analysis of groundwater quality in and around Tambaram taluk, Kancheepuram district,International Journal of Civil Engineering and Technology,V-8,I-8,PP-1362-1369,Y-2017

25. Arunya A., Sarayu K., Ramachandra Murthy A., Iyer N.R.,Enhancement of durability properties of bioconcrete incorporated with nano silica,International Journal of Civil Engineering and Technology,V-8,I-8,PP-1388-1394,Y-2017
26. Ilayaraja K., Krishnamurthy R.R., Jayaprakash M., Velmurugan P.M., Muthuraj S.,Characterization of the 26 December 2004 tsunami deposits in Andaman Islands (Bay of Bengal, India),Environmental

Earth

Sciences, V-66,I-8,PP-2459-2476,Y-2012

27. Ilayaraja K.,Morphometric parameters of micro watershed in Paravanar sub-basin, Cuddalore District,International Journal of Civil Engineering and Technology,V-8,I-8,PP-1444-1449,Y-2017

28. Ilayaraja K., Singh R.K., Rana N., Chauhan R., Sutradhar N.,Site suitability assessment for residential areas in south Chennai region using remote sensing and GIS techniques,International Journal of Civil Engineering and Technology,V-8,I-8,PP-1468-1475,Y-2017

29. Ilayaraja K., Reza W., Kumar V., Paul S., Chowdhary R.,Estimation of land surface temperature of Chennai metropolitan area using Landsat images,International Journal of Civil Engineering and Technology,V-8,I-8,PP-1450-1456,Y-2017

30. Chitra R.,Experimental study on beam using steel fiber and latex,International Journal of Civil Engineering and Technology,V-8,I-8,PP-1395-1403,Y-2017

31. Chitra R.,Analysis of traffic and management at Kovilambakkam intersection,International Journal of Civil Engineering and Technology,V-8,I-8,PP-1433-1443,Y-2017

32. Aswathy M.,Experimental study on light weight foamed concrete,International Journal of Civil Engineering and Technology,V-8,I-8,PP-1404-1412,Y-2017

33. Aswathy M.,Wastewater treatment using constructed wetland with water lettuce (Eichornia Crasipies),International Journal of Civil Engineering and Technology,V-8,I-8,PP-1413-1421,Y-2017

34. Kiruthiga K., Anandh K.S., Gunasekaran K, Assessment of influencing factors on improving effectiveness and productivity of construction engineers, 2015, International Journal of Applied Engineering Research, V - 10,I -17,p -13849-13854.

\section{AUTHORS PROFILE}

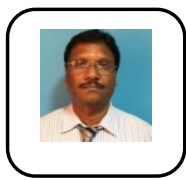

R.Venkatakrishniah Associate Professor, Department of Civil Engineering, Bharath Institute of Higher Education and Research, Chennai, India.

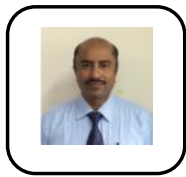

P . Dayakar Associate Professor, Department of Civil Engineering, Bharath Institute of Higher Education and Research, Chennai, India.

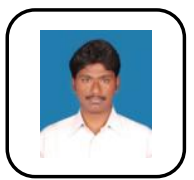

K. Venkat Raman Assistant Professor, Department of Civil Engineering, Bharath Institute of Higher Education and Research, Chennai, India 